\title{
ダム上下流における底生動物群集の試験湛水 開始前後の比較 COMPARISON OF BENTHIC INVERTEBRATE ASSEMBLAGES BETWEEN PRE AND AFTER IMPOUNDMENT AT UP- AND DOWNSTREAM OF DAM
}

\author{
高橋陽一 1 ・藤野 毅 2 ・ニン ウィリ 3 ・浅枝 隆 4 \\ Yoichi TAKAHASHI, Takeshi FUJINO, Hnin WITYI and Takashi ASAEDA \\ 1正会員 工学士 (財)水資源協会＼cjkstart水資源研究所（干103-0026 東京都中央区日本橋兒町22-6） \\ 2正会員 工博 埼玉大学准教授 大学院理工学研究科（干338-8570 さいたま市桜区下大久保255） \\ 3非会員＼cjkstart埼玉大学大学院生 大学院理工学研究科（†338-8570 さいたま市桜区下大久保255） \\ 4正会員 工博 埼玉大学教授 大学院理工学研究科（†338-8570 さいたま市桜区下大久保255）
}

\begin{abstract}
This topic presents the effect of water temperature on benthic invertebrate growth and assemblages at downstream site of the Dam in winter, in Japan. The surface layer water of dam was released, and the temperature was always 3-5 degrees higher than the upstream. This was because of tentative manipulation of dam. Life cycles of dominated species were faster and their body size were all larger in the downstream than the upstream. Kamimuria tibialis (Perlidae) as a predator grew faster. Also, its body weight was much heavier than in the upstream, even its body length is the same in the upstream. Periphyton biomass was also much higher, especially, filamentous species were dominated at slow current site in the downstream. Regardless of abundance of periphyton, Heptageniidae as a grazer were not increased compared with the upstream. Besides discharge control, water temperature changes invertebrate assemblages quickly. This result implies that restrict of the movement of species is need to consideration.
\end{abstract}

Key Words : Benthic invertebrate, Organic matter transport, Dam, Flood, Water Temperature

\section{1.はじめに}

ダムの上下流間で底生動物群集が変化する現象に関 する研究は，欧米先進国を中心に1980年代以降盛んに なり, 流量の変動による現存量の変化や流下物との関 連，ダム放流水温が下流の底生動物の生活史に影響な どについて多数報告がなされている1).

一方，国内では，河川生態学として古くから底生動 物種に関する生物学・生態学的特性について盛んに研 究がなされてきているものの2), ダム建設による上下流 間の不連続性が与えるインパクトに関する報告は比較 的最近である ${ }^{4)}$. 底生動物群集のハビタットは出水に よって様々な規模で破壊と回復を繰り返し，加えて， ダム運用によって流量が制限されたり, ダム湖の出現 により流下物の量や質が異なることで, 取り巻く環境 はより複雑になっている. そのため, 流域の構成種の 季節変動や異なる流域間での相違について適切に評価 することは困難であった．このように，河川生態系の 研究として, 個々の種の生物については, 生態学的観 点で多くの知見が得られているが，ダムが存在する河 川の環境管理の観点から, ダムの建設によって底生動
物群集がどのように変化するかを適切に評価するため には，すでに完成し，長年運用しているダムの上下流 の比較だけでは不十分であり, ダム出現前後の比較を 行うことが望ましいものの，そのような事例はほとん どない, 従って, 現状では, 河川生態系の保全を考慮 したダムの運用管理に反映させることが困難である.

このような背景のもと，本研究では，完成間近のダ ムを対象に試験湛水開始前後において底生動物種のモ ニタリングを実施し，その運用によって生ずる物理化 学的環境の変化が底生動物群集に与える影響と変動を 解明し，今後のダム本格運用における下流域の河川生 態系の管理に資する知見を得ることを目的としている.

\section{2. 調査方法}

\section{(1) 調査地点}

底生動物群集の調査は，2005年10月にから試験堪水 を開始した荒川水系中津川の滝沢ダム(埼玉県秩父市大 滝)の上流である中双里地区とダム直下(ダムサイトから 約 $400 \mathrm{~m}$ 下流、途中に流入する沢や支流は無く、ダム工 事区域外)に位置する小双里地区で行った(図-1). 


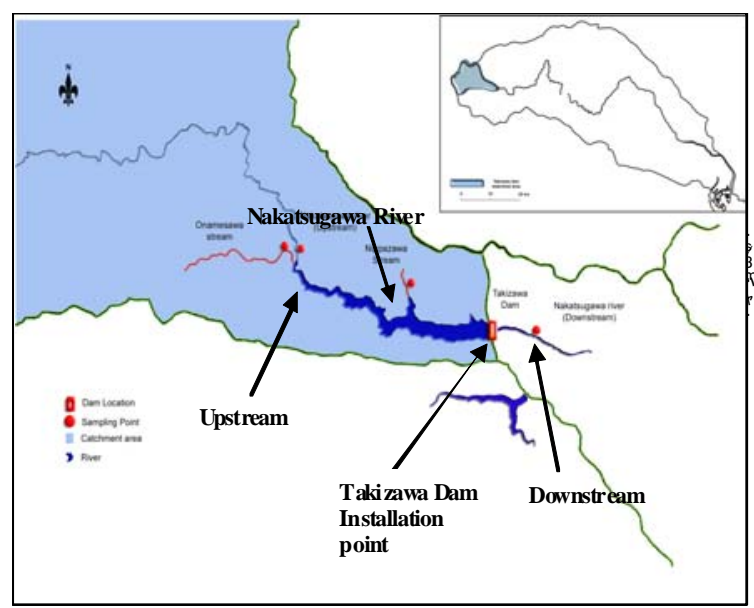

図-1＼cjkstart調査地点(埼玉県秩父市大滝 滝沢ダム)

\section{（2）調查方法}

底生動物については独立行政法人水資源機構滝沢ダ ム建設所（現荒川ダム総合事業所）による自然環境調 査の一環として，1995年から96年にかけて冬(12月), 早 春(3月), 夏(8月)に実施されており，以降，2004年から 05年，2005年から06年，2006年から07年において同様 の季節で行われている3 ${ }^{3}$ 。この調査では，本研究と同じ 区域の瀬を対象に, 各2か所採取し, 限りなく種類まで 同定され，個体数および湿潤重量が計測されている.

以上に加えて，著者らは2004年3月より月1回以上の 頻度で定期サンプリングを行い，科レベルまでの同定 (一部は種レベルまで)と個体数の定量調査を行った.

\section{（3）ダム上下流の物理環境，水質}

図-2 はダム流入量と放流量の経時変化を示す。滝沢 ダムでは試験湛水開始前まではバイパスを通して下流 の流量を維持しており，2005年10月1日に試験堪水を開 始したものの11月13日に湖岸斜面に変状が生じたため その対策工事を実施するため変状が観察される前の水 位に水位を下げて保ち，対策工事が完了した後，2006 年8月19日以降に再び堪水を開始している. 試験堪水期 間中の下流への放流量は，流入量が $0.5 \mathrm{~m}^{3} / \mathrm{s}$ に満たないと きは流入量であり，流入量が $0.5 \mathrm{~m}^{3} / \mathrm{s}$ 以上のときは $0.5 \mathrm{~m}^{3} / \mathrm{s}$ である。

過去3年間で，年間数回にわたる出水が発生しており 2005年10月の試験湛水開始から2007年3月までの期間に おいて最も規模が大きかったのは2006年10月7日の出水 で，その時の流入量のピークは $117.1 \mathrm{~m}^{3} / \mathrm{s}$ (日平均值) で あった．流出のピークは翌8日で $55.6 \mathrm{~m}^{3} / \mathrm{s}$ (日平均值) で あった. 出水時と試験堪水期間を除いた平水時では流 入量と放流量は同じである.

表-1に，中双里と小双里調査区内における平水時の瀬 の流速と水深を示す(毎回3か所計測). 両者の比較とし て，水深はほぼ同じであるが，ダム下流の流速はダム 上流と比較して年間を通じて低かった，写真-1は，両調 査区地点周辺の河床である. ダム下流において粗碟が

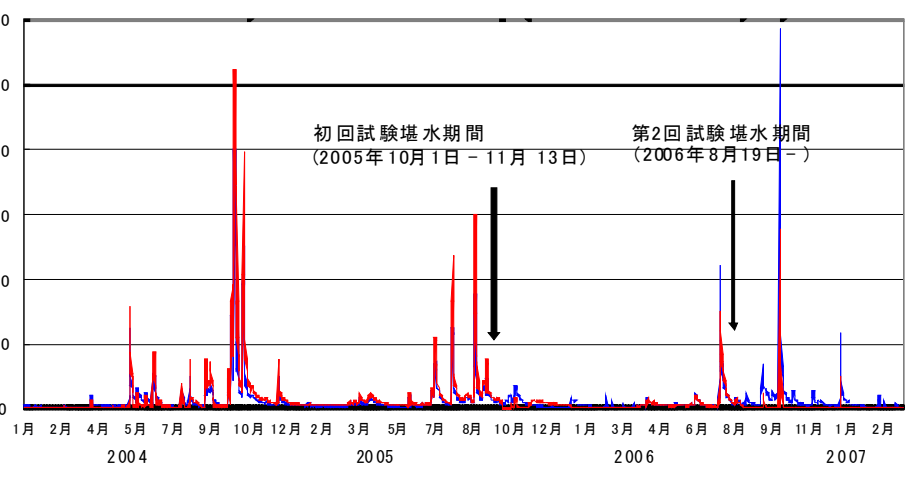

図-2 ダム流入量と放流量 (青は流入量, 赤は放流量，単位 $\mathrm{m}^{3} /$ 日)

表-1 調査区内の瀬の流速と水深（平水時）

\begin{tabular}{lcc} 
& 中里双(ダム上流) & 小里双(ダム下流) \\
流速 $(\mathrm{m} / \mathrm{s})$ & $0.61(0.31-0.84)$ & $0.31(0.10-0.55)$ \\
水深 $(\mathrm{cm})$ & $29(19-41)$ & $32(22-43)$ \\
\hline
\end{tabular}

※2006年、12回の平均とレンジ(カッコ内は最小—最大)

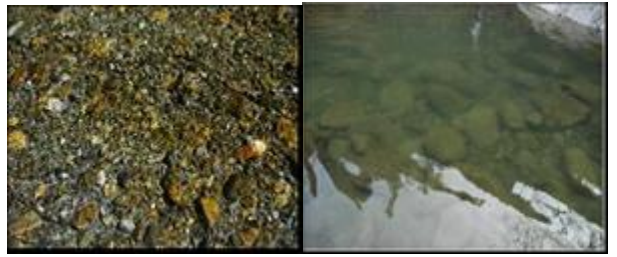

写真-1 河床の磁の状態 (左 : ダム上流, 右 : ダム下流)

\begin{tabular}{cccc}
\multicolumn{2}{c}{ 表-2 } & \multicolumn{3}{c}{ ダム上流域の水質の年平均值とレンジ } \\
\hline $\mathrm{pH}$ & $8.1(7.4-8.5)$ & $\mathrm{Temp}(\mathrm{C})$ & $9.2(0.6-19.2)$ \\
$\mathrm{DO}(\mathrm{mg} / \mathrm{l})$ & $11.4(8.7-15.7)$ & $\mathrm{EC} \mathrm{(mS/m)}$ & $20.6(15.8-31.6)$ \\
$\mathrm{DOC}(\mathrm{mg} / \mathrm{l})$ & $1.57(0.88-2.67)$ & $\mathrm{NO}_{3}-\mathrm{N}(\mathrm{mg} / \mathrm{l}) 0.80(0.54-1.10)$
\end{tabular}

$\underline{\mathrm{PO}}_{4}-\mathrm{P}(\mathrm{mg} / \mathrm{l}) \quad<0.002$

多く占めており，この状態は試験湛水開始前の2005年 に実施された河床碩サイズ分布の調査結果からも統計 上同様な結果が確認されていた3)。しかし，それがダム 建設によるものかは不明である。また，2006年以降， 巨碩表面には糸状藻類が繁茂している.

現地では, 水温, $\mathrm{pH}$, 溶存酸素, 電気伝導度を現地 用簡易水質計，濁度を濁度計(いづれも東亜DKK製)で計 測した。また採取した水について，実験室でTDN， TDP，溶存有機態(DOC), Chl- $a$ 濃度を測定した. Chl- $a$ 量の定量はターナー社の蛍光光度計を用いた. ダム下 流の水質は, 水温を除いてダム上流と比べて有意な差 は生じなかった。

\section{（4）流下物 ·付着藻類の採取}

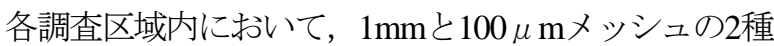
類の網を10分間設置し流下物を採取した。流下物を $1 \mathrm{~mm}$ 以上(CPOM) と $1 \mathrm{~mm}$ 以下 $(\mathrm{FPOM})$ に分けて実験室で $45^{\circ} \mathrm{C}$ で乾燥し, 重量および分析に用いた。 また, 砶の 付着藻類のサンプリングを行い，Chl- $a$ 量を測定した. 


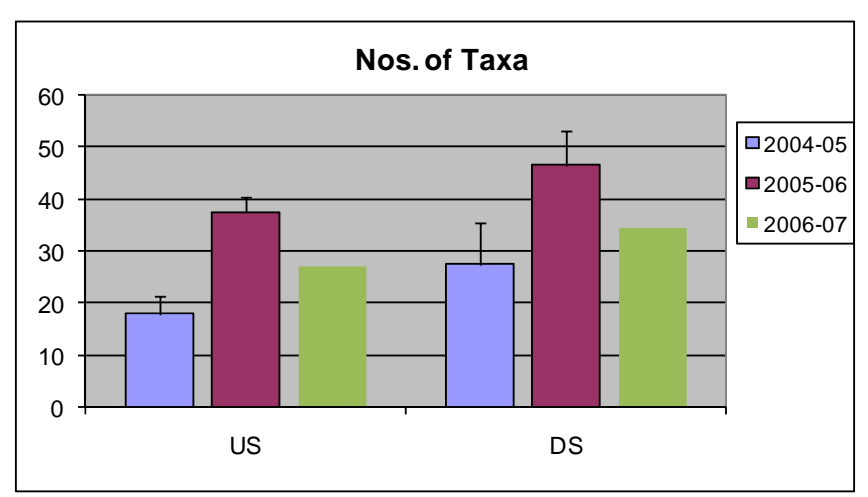

図-3＼cjkstart底性動物群集におけるタクサ数の流域間比較

(図中US：上流域, DS : 下流域)

$(P<0.0001$, two-way ANOVA $)$

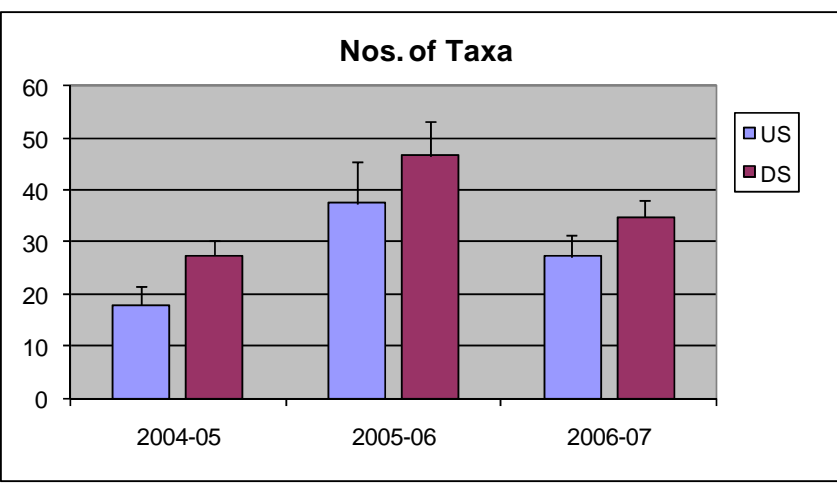

図-4 同タクサ数の調査年度間比較

(図中US：上流域, DS : 下流域)

$(P<0.001$, two-way ANOVA)

\section{3. 底生動物群集の結果}

\section{（1）底生動物群集の変動}

過去10年間に実施した滝沢ダム周辺における底生動物 出現種のうち, 昆虫は全8目，60科，172種が確認されて いる. ここでは, 試験堪水開始前後の底生動物種の動態 を把握することが目的であるため, 自然環境調査により 連続的に実施した2004年以降に実施したデータを評価対 象とする3). その中で，種類や個体数が多く発見される カゲロウ目，カワゲラ目，アミメカゲロウ目，コウチュ ウ目，八エ目，トビケラ目を対象種とした.

$50 \mathrm{~cm}$ 四方の面積あたりの底生動物における出現タク サ数と個体数の流域間変動, および調査年度間変動の有 意性を確認するため，それぞれ二次元配置分散分析を 行った. まず, タクサ数に関して, 流域間比較, および 調査年度間比較それぞれの変動には有意性が認められた (図-3, 図-4). なお，採取年ごとに出現タクサ数は異なっ ているが，その変化傾向は上流も下流も同じであること から，両者に共通する撹乱の要因としては，まず出水が 挙げられる. 出現タクサ数の変動は, その年に発生した 出水の規模や頻度，および時期に依ることが考えられる. 一方で，調査年度間比較においては，どの年度も下流域 でタクサ数が多いことが示された。 これは流域間での物

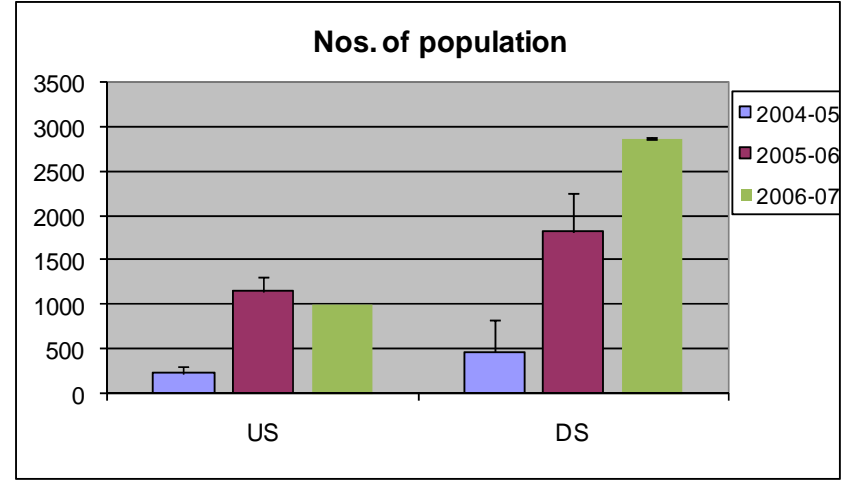

図-5 底性動物群集における個体数の流域間比較

(図中US：上流域，DS：下流域）

$(P<0.01$, two-way ANOVA)

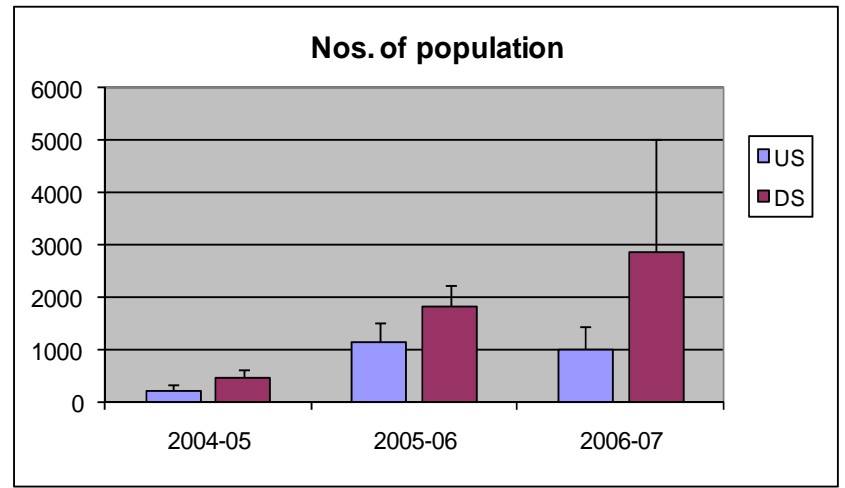

図-6 同個体数の調査年度間比較

(図中US：上流域，DS：下流域)

$(P=0.025$, two-way ANOVA)

理環境の違いに由来する付着藻類量の違いや捕食者とし ての魚類の量の違いなどが考えられる. しかし, 以上の タクサ数に関する解析のみからでは, ダム操作前後によ る明確な変動は生じていないことが示されている.

次に，個体数に関して，流域間比較，および調査年度 間比較それぞれの変動にも有意性が認められた. しかし， 下流の06-07年の偏差が特に大きく，タクサ数の解析ほ ど高い信頼性は得られていない(図-5, 図-6). 流域間比較 において，上流(US)での個体数は04-05年から05-06年に かけて増加したものの，翌06-07年では変化は見られな かった. 一方，下流(DS)ではこの期間中に増加し続けて いる．調査年度比較においては，どの年度においても個 体数は下流のほうがより多いことを示している. 但し, タクサ数に関する解析と同様に，個体数に関する解析の みからではダム操作前後による明確な違いは説明できな い. しかしながら，両方の05-06年から06-07年にかけて の変化を比べると, ダム下流ではタクサ数が減っている ものの，個体数が増加しており，ユスリカ等いくつかの 種類が卓越して生息していることを示唆している.

\section{（2）上流および下流の優占種とその摂食型}

ダム上流と下流の底生動物の構成タクサ数の相違につ いて, 2004年以降8回の個体数定量調査のうち, 上流域 のみに出現した種類と下流域の夕に出現した種類を示す. 
表-3 上流域のみにおいて出現した種(左)と下流域のみにおいて出現した種(右)一覧および摄食機能群3)

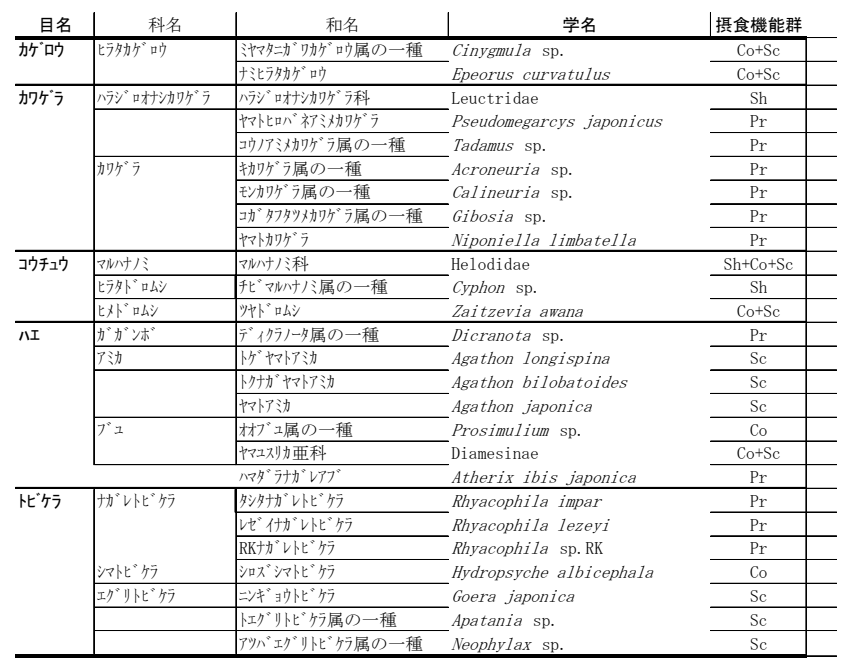

注1)摄食機能のCoは採集食者、Prは捕食者、Scは刈取食者、Shは破砕食者を示す。 注2)下流域の○は、ダム試験運用開始以降の調査で出現が確認された種を示す。
また，それぞれの摂食機能群を右に付記した(表-3). な お，これらは各流域で毎回出現したとは限らず，期間中 一度以上出現したものとして挙げている.これより下流 域のほうがタクサ数は多いことがわかる．摂食機能群に 着目すると，捕食者 $(\mathrm{Pr})$ 老除く採集食者 $(\mathrm{Co})$, , 刈取食者 (Sc)，破砕食者(Sh)の中で，上流域では刈取食者種が多 いのに対し，下流域では採集食者が多いことがわかる.

なお，ダム下流域においては，試験湛水開始以降に出現 した種類は17種あった。

\section{（3）流下有機物の比較}

表-4は，著者らが実施した試験湛水開始後の2006年4 月から2007年3月において採取した流下有機物の成分を 示す．流下有機物は $1 \mathrm{~mm}$ サイズ以上の粗粒状有機物之 $1 \mathrm{~mm}$ サイズ以下の細粒状有機物に分類し，それぞれの強 熱減量(AFDMとして表示), 炭素, 窒素含有率, 細粒状 有機物のリグニン含有率およびChl- $a$ 含有率を示す. 粗 粒状有機物はほとんどがリーフリターであり，ダム下流 は主に落葉期にダム下流域において移入したものである。 これより，流下物の質の違いについては，ダム下流の細 粒状有機物は植物プランクトン由来が多い.

粒状有機物の流下量については，ダム上流域では10〜 12月の落葉期こそ粗粒状が細粒状と比較して数10倍の規 模で流下し，密度に換算して $0.2 か ら ~ 0.4 \mathrm{~g} / \mathrm{m}^{3}$ であった。 それ以外の時期では，細粒状の占める割合が高い場合も 多く，密度に換算して0.01から $0.05 \mathrm{~g} / \mathrm{m}^{3}$ であった。一方， ダム下流においては，落葉期においても上流からの供給 量は少なく, 逆に割合は数分の 1 か数十分の 1 の規模で あった．密度に換算して最大でも $0.1 \mathrm{~g} / \mathrm{m}^{3}$ 以下であり, 多 くが 0.01 から $0.03 \mathrm{~g} / \mathrm{m}^{3}$ 程度であった.

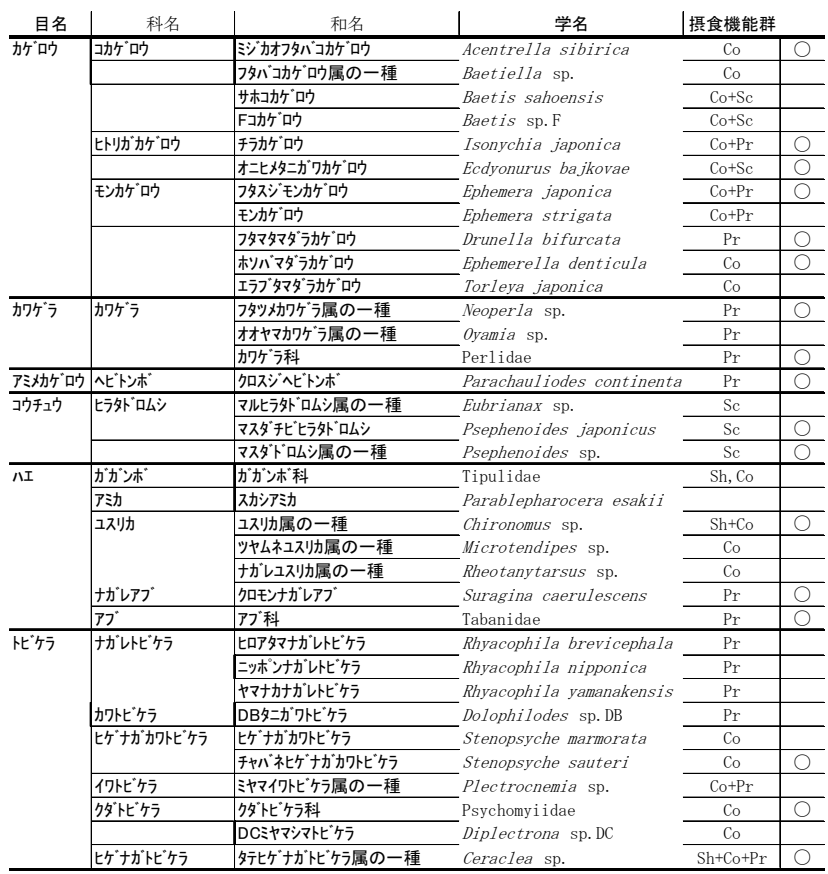

表-4 流下有機物の成分

\begin{tabular}{lcc}
\hline \multicolumn{2}{c}{ (Average (std.) in 2006, $\mathrm{n}=12$ ) } & \\
CPOM & upstream & downstream \\
AFDM (\%) & $96.9(1.25)$ & $90.6(4.98)$ \\
C content (\%) & $47.2(2.32)$ & $45.4(3.75)$ \\
N content (\%) & $1.4(0.90)$ & $1.5(0.60)$ \\
( C C $\mathrm{N}$ & 33.7 & $30.3)$ \\
FPOM & upstream & downstream \\
AFDM (\%) & $66.5(9.56)$ & $42.9(7.35)$ \\
C content (\%) & $33.1(4.78)$ & $15.6(5.36)$ \\
N content (\%) & $2.1(0.69)$ & $2.2(0.60)$ \\
( C/N & 15.8 & $7.1)$ \\
Lignin (\%)* & 27 & 8
\end{tabular}

Chl-a in water (micro g/L) $\quad 0.1-0.3 \quad 10.0-30.0$

* sampled in August, >250 micro m size

\section{4. ダム下流域の底生動物群集の変化}

2. (2)に示した通り, ダム上下流において, 試験湛水 開始後の主な環境の変化は流速の低下と水温である. 特 に, 水温は, ダム放流が表層水であり, ダム湖内で滞留 している間に暖ためられており, 運用後, 常に $3^{\circ} \mathrm{Cから}$ $5^{\circ} \mathrm{C}$ 高くなっている. 特に, 冬季では, 上流の水温が $0{ }^{\circ} \mathrm{C}$ 近くまで低下寸るのに対して，下流では $4^{\circ} \mathrm{C}$ 以上が保た れており, 多くの底生動物が一年中成長可能な温度領域 内にある. ダム放流水温の下流域の底生動物の成長に及 ぼす影響は多く報告がある5,6). Raddum et al.(1993)は, 水温の低い深層から放流されたことで，コカゲロウの一 種(B. rhodani)の個体数が減少すること, 一方, 冬季の放 流水温が高い場合は個体数が増加し, 成長も速くなった. 
著者らによる実施調査ではこれらの種は確認されてお らず，ダム試験湛水開始後，顕著に出現したのはチカラ カゲロウ科，ヒラタドロムシ科，ヒゲナガカワトビケラ, ナガレトビケラ科であった。 ここで，ヒゲナガカワトビ ケラは東アジア特有の種であり, 我が国において比較的 温暖な中流域に生息し，礫間に巣を作り，流下寸る植物 プランクトンを集めて捕食していることからダム下流域 においても優占することが報告されている，そこで，こ こではヒゲナガカワトビケラを中心に考察する.

ダム直下において，ダム運用前までのヒゲナガカワト ビケラの個体数は少なく，そのピークは明確ではないが， 運用後，ヒゲナガカワトビケラは年2世代を経過する. こうした生活史は，わが国の河川においては主に中流域 で見られ，高緯度地域や上流では年1世代である場合が 多い．ヒゲナガカワトビケラが定着する物理条件として, 河床の粗碟が多いことと，ダムによる出水時の放流量の 制御とそれに伴う土砂供給の減少が考えら，運用前にそ れらは寸でに整っていた. 今回，ここで見られた個体数 の増加と年2世代の出現は，この物理環境に加えて下流 水温の上昇が大きく影響している．ヒゲナガカワトビケ ラの羽化は $13^{\circ} \mathrm{C}$ 以上で発生し，低温時はそれまで待って いることや，積算温度が55月 ${ }^{\circ} \mathrm{C}$ 達すると次の世代に経 過するまでに成長することが知られている7゙.

今回，冬季の水温がこれまで $4^{\circ} \mathrm{C}$ 以下であったのが， 常に $4{ }^{\circ} \mathrm{C}$ 以上となり羽化するまでの時期は大幅に短縮さ れた. また，出水時の擋乱によって，卵や第 $\mathrm{I} \sim \mathrm{II}$ 齢は 流下しや寸く，IV齢以上では巣が強固で安定するため生

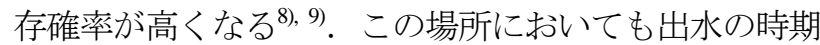
と羽化・産卵の時期が近いと生存確率は低くなるが，水 温の上昇によって, 少なくともダム上流や運用前のダム 直下と比べて羽化・産卵の時期がより早く生じ，出水発 生時にはすでにIV齢以上に達していることで生存確率が 高まる．個体数および幼齢分布の結果から，以上のよう な理由でダム直下においては出水による流下は少なかっ たことが考えられる，さらに，すでにニッチに関する物 理条件は整っていたため，水温が上昇したことにより下 流に生息したものが産卵のために溯上区域を拡大し，ダ 么直下での発生が規則的なものとなったことが考えられ る。このほか，ヒラタドロムシ科なども，もともと中流 域に生息する種であり，河川水温の上昇により生息域が 拡大したことが考えられる.

\section{5. 出水後の底生動物群集の回復の比較}

最後に，著者らの調査による2006年10月のダム上下流 での出水後の底生動物群集の回復について比較する. 出 水によって，底生動物は流下寸るが，同時に河床に堆積 していた餌資源も流される。ここでは，餌資源との関係 を見るため, 各摂食機能の代表的な種類について各個体

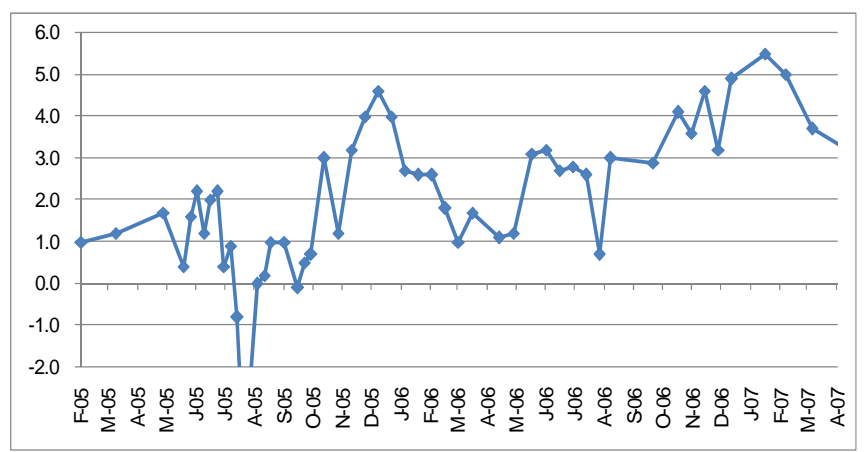

図-7 ダム上流域と下流域の水温差 (下流域-上流域) (単位は )

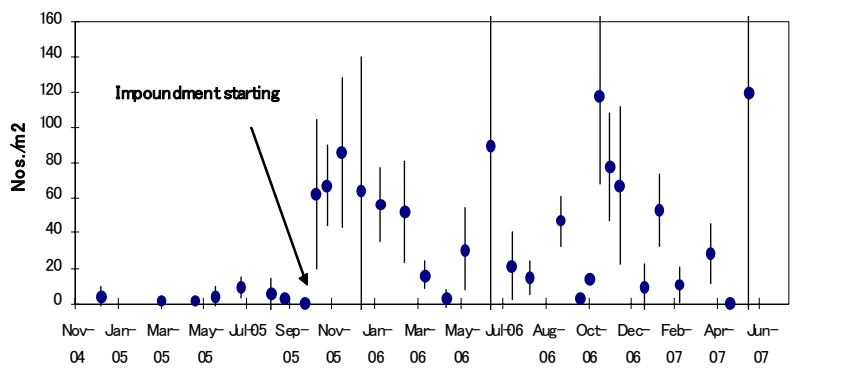

図-8ヒゲナガカワトビケラ個体数の経年変化 $(n=3)$

の乾燥重量を測定し，その平均と標準偏差を示した(図9(a)-(d)). 代表種は前出の採集食者としてヒゲナガカワ トビケラ，同じ造網型で採集食者（あるいはろ過摂食 者）のシマトビケラ科(Hydropsychidae)，刚菜食者(Sc)と してヒラタカゲロウ科(Heptageniidae)，および捕食者(Pr) としてカミムラカワゲラ種(Kamimuria tibialis)を選定した. まず，明確なことは，ヒゲナガカワトビケラ種一個体 の重量が大きく，さらに下流において秋から冬にかけて 急激に増加した．前出のとおり，これは水温が低下せず, 流下寸る細粒状有機物を捕食し成長し続けたことを示唆 する. 一方，上流域でのヒゲナガカワトビケラのバイオ マスはほとんど増加していない. 次に, 同じ造網型のシ マトビケラ科については，下流域のほうがやや重量が大 きめであるが，変動傾向は上流域と同じ傾向にあった. この流域で確認されたシマトビケラ科は5種あるが，い づれもダム上下流に生息が確認されている。 下流域の温 度の上昇の影響は見られなかった。もともとはその個体 数は上流域のほうがこの時期に流下寸るシマトビケラ科 やカミムラカワゲラ種も下流に多い傾向にある. 一方, ヒラタカゲロウ科は上流域で回復傾向が確認できるが, 下流域ではそれが見られない，下流域は付着藻類がより 多く繁茂しているにも関わらず，増加傾向にないのは， この種は滑行型としても区別され，糸状藻類が繁茂する 礫の表面は不利に働いたことが考えられる4)．捕食者で あるカミムラカワゲラ種も，体長および個体の重量は下 流で大きい傾向があるが，変動は上流と同じであった. 


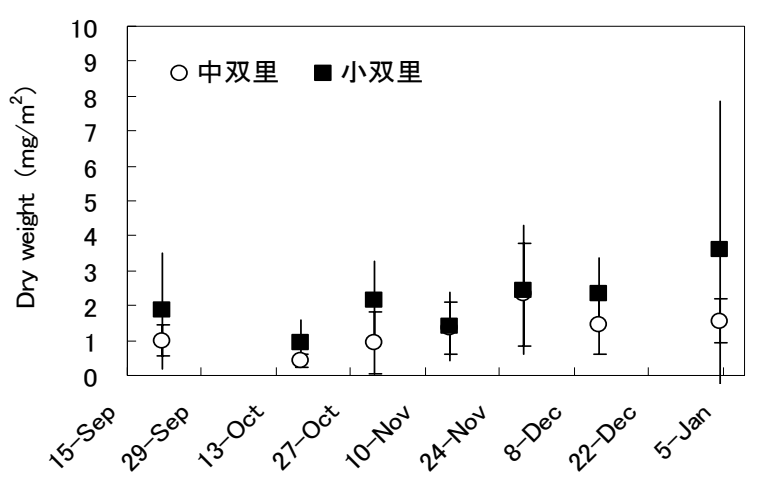

(a) シマトビケラ科 (Hydropsychidae)

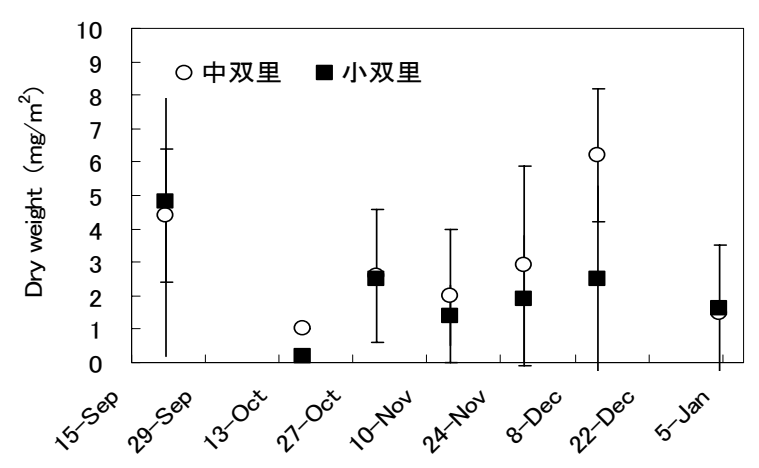

(c) ヒラタカゲロウ科 (Heptageniidae)

図-9 出水後の底生動物個体 (重量) の変化 $(n=3)$

\section{6. おわりに}

本研究により，ダムの試験湛水開始前から生物モ二タ リングを行ったことで, 複雑なダム出現による底生動物 群集の変化の動態をある程度把握することができた．注 意すべきことは，実施年度によって出現タクサ数や個体 数は大きく異なるので，評価は断続的なモニタリングの もとで行われるべきである.

今回の結果から, 試験湛水開始以前からダム上下流で 生息種や密度が異なっていること, 試験湛水開始後に よって環境の変化が生じた後に変化が生じることの $2 つ$ の相違パターンが確認された。この区別は運用前の調査 が不可欠であり，変化する環境要因との関係を評価する 上で大変重要である．また，水温の変化に著しく反応す る種とそうでない種があることがわかった。

謝辞：ダム流入および放流量, 滝沢ダム自然環境調査結 果については独立行政法人水資源機構荒川ダム総合事業 所より提供頂きました．また，サンプルの採取や物理環 境の測定においては忘用地質(株)のご協力を受けました. 記して感謝いたします。

本研究は, 水資源協会と埼玉大学の共同研究「山地渓 流河川における生態系の評価手法に関寸る研究」として 行われた。また，一部は文部科学省科学研究費(基盤 (C))No. 19560509によって行われた.

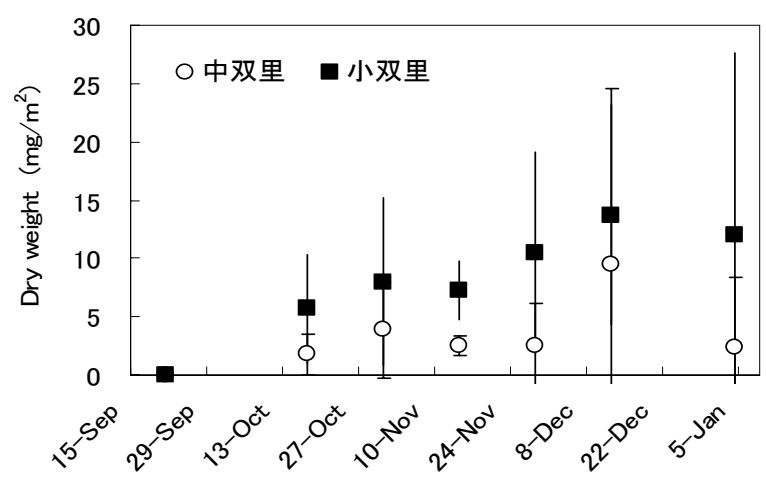

(b) ヒゲナガカワトビケラ (Stenopsyche marmorata)

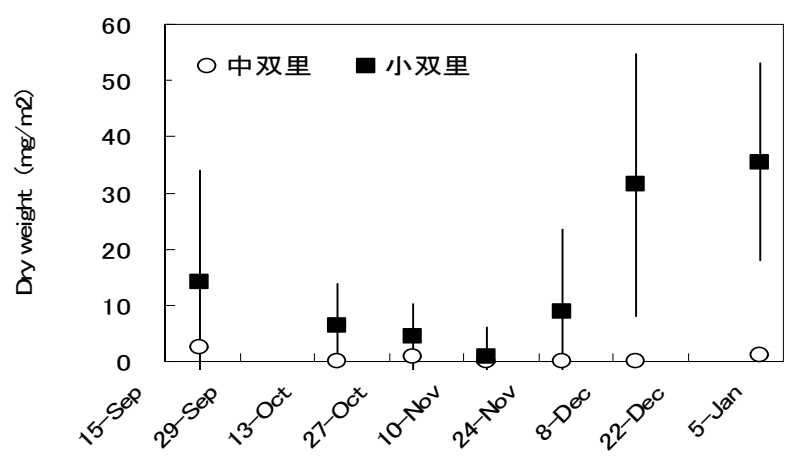

(d) カミムラカワゲラ (Kamimuria tibialis)

(O: 中双里 (ダム上流)、○: 小双里 (ダム下流)

\section{参考文献}

1) 例えばDoeg, T.J., et al.: Response of the aquatic macroinvertebrate communities to dam construction on the Thomson river, Southeastern Australia, Reg. Rivers, Vol.1, pp.-195-209, 1987.

2) 津田早苗: 水生昆虫の生態学, 水生昆虫学第2章, 北隆館, 1962.

3) 関東地方ダム等フォローアップ委員会, 第3回滝沢ダムモニ タリング調查結果資料集, 2006

4) 波多野圭亮, 竹門康弘, 池淵周一: 貯水ダム下流の環境変化 と底生動物群集の様式, 京都大学防災研究所年報, 48B, 2005.

5) R. Cereghino, Abundance, biomass, life history and growth of six Trichoptera species under natural and hydropeaking conditions with hypolimnetic releases in a Pyrenean stream, Arch. Hydrobiol. 138, pp.307-328, 1997.

6) Raddum G.G. and A.Ejellheim, Life cycle and production of Baetis rhodani in a regulated river in western Norway, Reg. Rivers, Vol.8, pp.-49-61, 1993.

7) 御勢久右衛門 : ヒゲナガカワトビケラの生活史と令期分析, 陸水学杂隹誌, 31, pp.96-106, 1970.

8) Nishimura, N.: Ecological studies on the net-spinning caddisfly Stenopsyche griseipennis McLaclan. 1. Life history and habit. Mushi, 39, pp.103-114, 1966.

9) Nishimura, N.: Ecological studies on the net-spinning caddisfly Stenopsyche marmorata NAVAS 6. Larval and pupal density in the Maruyama river, Physiol. Ecol. Japan, 21,pp.1-34, 1984.

(2007. 9. 30受付) 